\title{
CHANGING TRENDS OF MATERNAL MORTALITY IN KRISHNA HOSPITAL, KARAD FROM 2012 TO 2014
}

\author{
Zainab Nayani1, Vaishali Vahwal2, Parimita Khot ${ }^{3}$, Sneha Nagar4, Navina Singh ${ }^{5}$ \\ ${ }_{13}^{\text {rd }}$ Year Resident, Department of Obstetrics and Gynaecology, Krishna Institute of Medical Sciences, Karad. \\ ${ }^{2}$ Assistant Professor, Department of Obstetrics and Gynaecology, Krishna Institute of Medical Sciences, Karad. \\ 32nd Year Resident, Department of Obstetrics and Gynaecology, Krishna Institute of Medical Sciences, Karad. \\ 43rd Year Resident, Department of Obstetrics and Gynaecology, Krishna Institute of Medical Sciences, Karad. \\ 53rd Year Resident, Department of Obstetrics and Gynaecology, Krishna Institute of Medical Sciences, Karad.
}

\section{ABSTRACT}

\section{BACKGROUND}

The aim of this study was to evaluate the causes of maternal deaths in Krishna Institute of Medical Sciences, Karad.

\section{MATERIALS AND METHODS}

A three years retrospective study from January 2012 to December 2014.

\section{RESULTS}

MMR in the year 2012, 2013 and 2014 were 340, 234 and 148 per 100,000 live births respectively. There has been a gradual decline in the maternal mortality ratio at Krishna Hospital, Karad over last three years.

\section{CONCLUSION}

Proper antenatal care, emergency obstetrics care and routine audits for maternal mortalities are needed to decrease the maternal mortality as well as to evaluate the trends of maternal deaths. This will help to develop subsequent policies and protocols to tackle life threatening obstetric emergencies.

\section{KEYWORDS}

Maternal Mortality, Comparative Study in MMR, Changing Trends in MMR.

HOW TO CITE THIS ARTICLE: Nayani Z, Vahwal V, Khot P, et al. Changing trends of maternal mortality in Krishna Hospital, Karad from 2012 to 2014. J. Evolution Med. Dent. Sci. 2017;6(12):944-946, DOI: 10.14260/jemds/2017/202

\section{BACKGROUND}

Maternal mortality is a sensitive public health indicator. World Health Organization (WHO)'s 10th revision of the International Statistical Classification of Diseases and Related Health Problems (ICD-10) defines maternal mortality as "the death of a woman while pregnant or within 42 days of termination of pregnancy irrespective of the duration and the site of the pregnancy, from any cause related to or aggravated by the pregnancy or its management but not from accidental or one incidental cause. ${ }^{1}$ Globally, there were an estimated 289,000 maternal deaths in 2013, a decline of 45\% from 1990. The sub-Saharan Africa region alone accounted for $62 \%$ $(179,000)$ of global deaths followed by Southern Asia at $24 \%$ $(69,000)$. At the country level, the two countries that accounted for one third of all global maternal deaths are India at $17 \%(50,000)$ and Nigeria at $14 \%(40,000)$. The global MMR in 2013 was 210 maternal deaths per 100,000 live births, down from 380 maternal deaths per 100,000 live births in 1990. The MMR in developing regions (230) was 14 times higher than in developed regions. Sub-Saharan Africa has the highest regional MMR (510). ${ }^{2}$

Financial or Other, Competing Interest: None.

Submission 27-07-2016, Peer Review 27-09-2016,

Acceptance 03-10-2016, Published 09-02-2017.

Corresponding Author:

Dr. Zainab Nayani,

\#202, Rafiq Panjwani,

Madni Palace, Next to Najafi House,

Nishanpada, X-Lane, Dongri-400009.

E-mail: zainabsnayani@gmail.com

DOI: $10.14260 /$ jemds $/ 2017 / 202$
The country with the highest estimated number of maternal deaths is India $(136,000)$, followed by Nigeria $(37,000)$, Pakistan $(26,000)$, Democratic Republic of Congo and Ethiopia (24,000 each), the United Republic of Tanzania $(21,000)$, Afghanistan $(20,000)$, Bangladesh $(16,000)$, Angola, China, Kenya (11,000 each), Indonesia and Uganda $(10,000$ each). These 13 countries account for 67 percent of all maternal deaths. ${ }^{3}$

Statistical measures of maternal mortality are maternal mortality ratio and maternal mortality rate.

\section{Maternal Mortality Ratio (MMR) ${ }^{4}$}

- Refers to the number of women who die as a result of complications of pregnancy or childbearing in a given year per 100,000 live births in that year.

\section{Maternal Mortality Rate 4}

- Maternal Mortality Rate is defined as the number of maternal deaths to women in the ages 15-49 per lakh women in that age group.

\section{Life Time Risk}

Life time risk is defined as the probability that women of reproductive age (15-49) will die due to child birth or puerperium assuming that chance of death is uniformly distributed across the entire reproductive span.

Maternal mortality rate which measures the risk of dying from pregnancy are highest in Africa. The index of quality of health services of a country is reflected by its maternal mortality ratio. Preventing maternal deaths remains one of the most important objectives of National Family Welfare Programme. 
India's maternal mortality rate (MMR), or the rate of deaths among women during or after pregnancy, declined to $16 \%$ in 2011-2012 from 2007-2009. Although the MMR dropped from 212 deaths per 100,000 live births in 2007 2009 to 178 in 2010-12, India was behind the target of 103 deaths per live births to be achieved by 2015 under the United Nations - mandated millennium development goals (MDGs). The MMR in southern states fell 17\% from 127 to 105, closer to MDGs. Assam and Uttar Pradesh were the worst performing states, with an MMR of 328 and 292, respectively. Kerala and Tamilnadu have surpassed the MDG with an MMR of 66 and 90, respectively. 5

\section{MATERNAL MORTALITY RATE (PER 100,000 LIVE BIRTHS)}

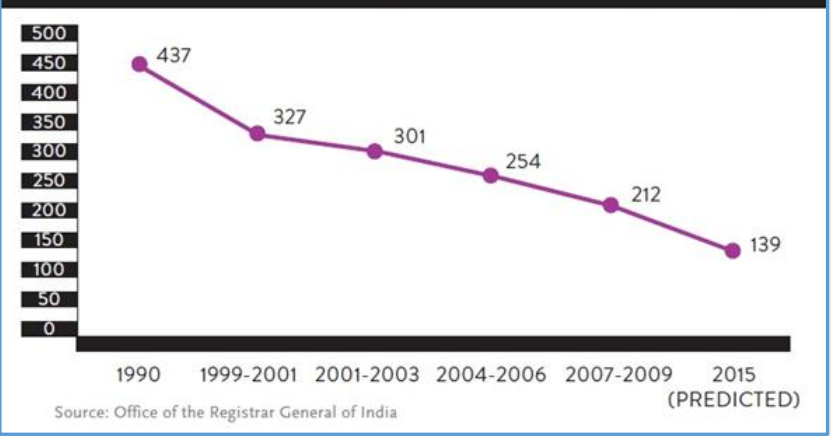

In India, the lowest MMR is in Kerala, 66 per lakh live births, followed by Maharashtra which is 87 per lakh live births. Then comes Tamil Nadu which is at 90 per lakh live births. Overall, the maternal mortality ratio in India in 2011, 2012, 2013 and 2014 were 206, 197, 189 and 181 respectively. 6 The aim of this study is to assess the maternal mortality ratio at a tertiary referral centre and to find out the leading causes of maternal deaths.

\section{MATERIALS AND METHODS}

Krishna Institute of Medical Sciences is a well-known referral centre in and around Karad Taluka in Satara district. It gets referrals from primary health centres, maternity homes, and polyclinics in Karad and from surrounding villages. Our study was carried out in Obstetrics and Gynaecology Department of KIMS. A retrospective study was carried out by reviewing the records of maternal deaths from the period between January 2012 to December 2014. Thirty four cases of maternal mortality were analysed with special emphasis on parity, age and antenatal care and death and cause of death.

\begin{tabular}{|c|c|c|c|c|}
\hline Age Year & $<\mathbf{2 0}$ & $\mathbf{2 0}$ to 29 & $\mathbf{3 0}$ to $\mathbf{3 9}$ & $\mathbf{4 0}$ to $\mathbf{4 9}$ \\
\hline 2014 & - & 7 & - & - \\
\hline 2013 & 1 & 9 & 2 & 1 \\
\hline 2012 & - & 11 & 4 & - \\
\hline \multicolumn{6}{|c|}{ Table 1. Distribution of Age } \\
\hline
\end{tabular}

Majority of deaths were between age group 20 to 29 years and minimum below 20 years.

\begin{tabular}{|c|c|c|c|}
\hline Age Year & Para 1 & Para 2 & Para 3 \\
\hline 2014 & 5 & - & 2 \\
\hline 2013 & 7 & 4 & 1 \\
\hline 2012 & 11 & 3 & 1 \\
\hline \multicolumn{3}{|c|}{ Table 2. Distribution of Parity } \\
\hline
\end{tabular}

Primipara had more mortality compared to Multipara.

\begin{tabular}{|c|c|c|c|}
\hline Year & $\begin{array}{c}\text { Booked } \\
\text { Cases }\end{array}$ & $\begin{array}{c}\text { Unbooked } \\
\text { Case }\end{array}$ & Total \\
\hline 2014 & 2 & 5 & 7 \\
\hline 2013 & 1 & 11 & 12 \\
\hline 2012 & 1 & 14 & 15 \\
\hline Table 3. Distribution of Booked and Unbooked Patients \\
\hline
\end{tabular}

Maximum deaths were seen in unbooked patients.

\begin{tabular}{|c|c|c|c|c|}
\hline $\begin{array}{l}\text { Sr. } \\
\text { No. }\end{array}$ & $\begin{array}{c}\text { Causes of } \\
\text { Death }\end{array}$ & 2012 & 2013 & 2014 \\
\hline 1 & $\begin{array}{c}\text { Sudden cardiac } \\
\text { arrest due to severe } \\
\text { MS and MR }\end{array}$ & 1 & 2 & - \\
\hline 2 & PPH with DIC & 2 & 1 & 2 \\
\hline 3 & $\begin{array}{l}\text { Ante Partum } \\
\text { Eclampsia } \\
\end{array}$ & 1 & & 3 \\
\hline 4 & $\begin{array}{l}\text { Acute Fulminant } \\
\text { Hepatic Failure } \\
\text { with Hepatitis B } \\
\text { and E }\end{array}$ & 1 & - & - \\
\hline 5 & $\begin{array}{c}\text { CCF with Severe } \\
\text { Anaemia }\end{array}$ & 2 & - & - \\
\hline 6 & $\begin{array}{c}\text { APE with cerebral } \\
\text { venous sinus } \\
\text { thrombosis } \\
\end{array}$ & - & 1 & - \\
\hline 7 & $\begin{array}{c}\text { Amniotic Fluid } \\
\text { embolism }\end{array}$ & - & - & 1 \\
\hline 8 & $\begin{array}{c}\text { Imminent } \\
\text { eclampsia with DIC }\end{array}$ & - & - & 1 \\
\hline 9 & Swine Flue & - & 3 & 1 \\
\hline 10 & $\begin{array}{l}\text { APH with abruptio } \\
\text { placenta }\end{array}$ & & 1 & 2 \\
\hline 11 & $\begin{array}{l}\text { DIC with septic } \\
\text { shock with dengue } \\
\text { fever }\end{array}$ & - & 1 & - \\
\hline 12 & $\begin{array}{c}\text { Imminent } \\
\text { eclampsia with } \\
\text { abruptio placenta }\end{array}$ & - & 1 & - \\
\hline 13 & $\begin{array}{l}\text { Thrombocytopenia } \\
\text { with severe } \\
\text { anaemia with CCF }\end{array}$ & - & 1 & - \\
\hline 14 & $\begin{array}{l}\text { DIC with renal } \\
\text { failure }\end{array}$ & - & 1 & - \\
\hline 15 & $\begin{array}{c}\text { Pulmonary } \\
\text { thromboembolism } \\
\text { with severe PIH }\end{array}$ & - & & 2 \\
\hline 16 & $\begin{array}{c}\text { Multi organ failure } \\
\text { due to DIC with } \\
\text { hepatitis }\end{array}$ & - & - & 2 \\
\hline 17 & $\begin{array}{c}\text { Severe PIH with } \\
\text { Hepatorenal Failure }\end{array}$ & - & & 2 \\
\hline 18 & $\begin{array}{c}\text { Amniotic fluid } \\
\text { embolism }\end{array}$ & - & - & 1 \\
\hline 19 & $\begin{array}{c}\text { Imminent } \\
\text { eclampsia with } \\
\text { DIC } \\
\end{array}$ & - & - & 1 \\
\hline
\end{tabular}

\section{RESULT}

Discussion

During the period from January to December 2012, 2013 and 2014 , the number of total births in our maternity department were 4731, 5131 and 4406 and maternal deaths were 15, 12 and 7 respectively, giving an MMR of 340, 234 and 148 per 100,000 live births respectively. 
Large number of patients were referred at terminal stages from nearby hospitals which is a major cause of death. APH, $\mathrm{PPH}$ and eclampsia are one of the major causes leading to maternal mortality. Improved emergency management at the primary level has improved the outcome, leading to gradual decline in the MMR over these years.

\section{CONCLUSION}

Pregnancy and labour are physiological processes but lack of a proper place, skilled hand and timely referral to specialised unit causes mortality. Training in emergency obstetric care has created some awareness among doctors and midwives. The training should percolate among interns, house surgeons, residents and health guides too. Practise and knowledge of basic aseptic techniques is essential at all levels. Testing kits for hepatitis $\mathrm{B}$ and $\mathrm{E}$ should be available at all tertiary maternity centres. Routine iron and folic acid supplementation is of proven value. Proper antenatal care, emergency obstetrics care and routine audits for maternal mortalities are needed to decrease the maternal mortality as well as to evaluate the trends of maternal deaths and that will help to develop subsequent policies and protocols to tackle life threatening obstetric emergencies.

\section{REFERENCES}

[1] World Health Organization. International statistical classification of diseases and related health problems. tenth revision. Tabular list, instruction manual. Geneva 1992; Vol 1, 2.

[2] World Health Organization. Trends in maternal mortality: 1990 to 2008 estimates developed by WHO, UNICEF, UNFPA and the World Bank. Geneva 2010.

[3] Maternal mortality in 2000. Estimates developed by WHO. Geneva: UNICEF and UNFPA. World Health Organization 2004.

[4] WHO health statistics and information systems. http://www.who.int/healthinfo/statistics/indmaternal mortality/en/

[5] Special bulletin on maternal mortality in India 2010 2012.

[6] http://www.censusindia.gov.in/vital_statistics/SRS_Bul letins/MMR_Bulletin-2010-12.pdf

[7] Maternal mortality ratio (modeled estimate, per 100, 000 livebirths).

http://data.worldbank.org/indicator/SH.STA.MMRT 